\title{
Application of Social Competence (ASCAAL) to improve student learning creativity in the online learning system (SPADA) in the Covid-19 Pandemic Era
}

\author{
Mungkap Mangapul Siahaan ${ }^{1 *}$, Rudiarman Purba $^{2}$, Tambos August Sianturi ${ }^{3}$ (D) \\ 1,2,3 University of HKBP Nommensen Pematangsiantar, Pematangsiantar, Indonesia
}

\section{A R T I C L E I N F O}

Article history:

Received September 08, 2021

Revised September 11, 2021

Accepted October 12, 2021

Available online November 25, 2021

\section{Kata Kunci:}

Kompetensi Social, Kreativitas, SPADA

Keywords:

Social Competence, Creativity, SPADA

DOI:

https://dx.doi.org/10.23887/jet.v5i4.4 0377

\begin{abstract}
A B S T RA K
Kompetensi sosial menjamin tercapainya tujuan pengajaran dalam sistem SPADA yang tidak mengenal batas ruang dan waktu bagi guru dan siswa. 54\% guru Indonesia tidak memiliki kompetensi yang cukup untuk mengajar. Hal ini berdampak pada kurangnya tujuan pembelajaran tidak tercapai secara maksimal. Penelitian ini bertujuan untuk menunjukkan investigasi kreativitas dua kelompok siswa dalam pembelajaran Struktur Sintaksis Bahasa Inggris. Dengan teknik purposive sampling, ASCAAL diukur dari hasil beberapa metode berupa angket, pretest dan posttest yang diberikan kepada 45 siswa. Kelompok tersebut adalah kelas kontrol dan kelas eksperimen yang mempelajari Struktur Sintaksis. Kelas eksperimen terdiri dari 25 siswa dan kelas kontrol terdiri dari 20 siswa. Satu kelompok mengajar dengan SPADA dan kelompok lainnya mengajar dengan kombinasi fasilitas media sosial seperti Google Classroom dan WhatsApp. Teknik yang digunakan untuk menganalsis data yaitu analisis deskriptif kualitatif dan kuantitatif. Hasil penelitian yaitu ASCAAL terbukti positif meningkatkan kreativitas siswa. ASCAAL juga mendukung positif sistem manajemen pembelajaran. Berdasarkan fitur dan menu pada SPADA menunjukkan sistem kreativitas belajar yang berkembang yang meningkatkan motivasi dan nilai siswa.
\end{abstract}

\section{A B S T R A C T}

Social competence ensures teaching objectives in the SPADA system that knows no boundaries of space and time for teachers and students. 54\% of Indonesian teachers do not have sufficient competence to teach. It has an impact on the lack of learning objectives that are not achieved optimally. This study aims to investigate the innovation of two groups of students in learning English Syntactic Structure. With purposive sampling technique, ASCAAL was measured from the results of several methods in the form of a questionnaire, pretest and posttest given to 45 students. The group is the control class and the experimental class that study Syntactic Structure. The experimental class consisted of 25 students, and the control class consisted of 20 students. One group teaches with SPADA, and the other teaches with social media facilities such as Google Classroom and WhatsApp. The technique used to analyze the data is descriptive qualitative and quantitative analysis. The result of the research is that ASCAAL is proven to be positive in increasing students' creativity. ASCAAL also supports a positive learning management system. The features and menus on SPADA show a developing learning creativity system that increases student motivation and value.

This is an open access article under the CC BY-SA license. Copyright (C) 2021 by Author. Published by Universitas Pendidikan Ganesha.

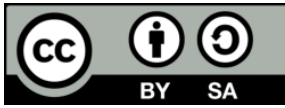

\section{INTRODUCTION}

Teaching methods as integrated connection system with teaching activities are understood as a bridge connecting teaching and learning interaction between teachers and students (Anuar et al., 2021; Gavrilenko, 2018; Mufit et al., 2020). Teaching activities must be conducted in interesting academic situations that enhance interaction, inspiration, collaboration, challenging and independence (Tsai et al., 2017; Uygarer \& Uzunboylu, 2017; Yilmaz \& Korur, 2021). The major purpose is the outcome of creativity, mindset, physiology, and independence of the students. Education world is a dynamic world and continually updated (Bettencourt et al., 2011; Bui \& Do Van Dung, 2019; Zendler \& Greiner, 2020). Based on teachers competences analysis of Education Department of Republic of Indonesia, 54\% of Indonesia teachers do not have enough competence to teach (Retnawati et al., 2016; Sundayana, 2015). Related to the Research Department of Republic of Indonesia, $30 \%$ of Indonesian students do not have enough cognitive competence to understand their teachers explanation (Chasanah, 2020; Jayadiputra \& Karim, 2020; Tyas et al., 2019). Social competence as an educational 
communication provides methods to connect people understanding in teaching systems, teaching interaction and social interaction (Dhiu, 2017; Jogezai et al., 2021; Liu, 2020). As it is explained through the Republic of Indonesia Standard National of Education Chapter 28 Verse 3 point D, social competence is teacher competence also known as society communication competences. These competences are used to construct effective communication to students, teachers, parents and other people both inside and outside the environment of education system (Gishti, 2018; Maulida et al., 2020; Tentama \& Riskiyana, 2020).

Teaching target of social communication in the era of 4.0 must accommodate the role of technology (Atabekova et al., 2021; Chan, 2021; Coffelt et al., 2019). The combination of new creation teaching methods today came up drastically in the era of the disruptive technology that was also triggered by the pandemic Covid19 (Bahasoan et al., 2020; Jogezai et al., 2021; Khan et al., 2021). Educational system as teaching methods and medias changed ways of communication in world of educational system (Tsai et al., 2017; Zendler \& Greiner, 2020). As the result of the condition, the presence of e-Learning arise higher using In-network Learning System (SPADA) (Dado \& Bodemer, 2017; Siripongdee et al., 2020; Suryandari, 2020). The application organizes entirely e-Learning-teaching activities that allow teaching materials delivery system from teachers to students or conversely using internet or medias of computer network (Ogbonna et al., 2019). Today, e-learning system is to be a must and used entirely in educational system world. This new learning system is to be a very popular apparatus to support an interactive virtual education (Al-Fraihat et al., 2020; Vrieling et al., 2012). The learning system or SPADA grants abundant teaching-learning access to teachers' material beyond the space and time. Students or teachers only need to prepare their own computer, laptop, smartphone and other medias as tool networks to use SPADA. Today, e-Learning is a vital media internet or intranet (Nácher, Badenes-Ribera, Torrijos, \& Ballesteros, 2021; Yusuf \& Widyaningsih, 2020). Using this application, teachers and students have their own privilege to explore and develop advance learning. Their appliers on internet have facilities such as speech access, time optimization, simplicity, efficiency and other supportable facilities (Asrial et al., 2020; Zhang et al., 2020). In the system, sides, teachers and students are active to develop their participations and activities in improving the learning quality and the verifying the effectiveness steps equally to obtain agile information (Ali \& Maksum, 2020; Nácher, Badenes-Ribera, Torrijos, Ballesteros, et al., 2021). SPADA becomes a preferable alternative in teaching and learning. The optimization of SPADA is supported by the enough social competence of teachers. The social competences are: Oral, writing and code competence, Using communication technology and information, Social relationship with people inside and outside educational environment, Building relationship effectively and efficiently. These social competences become social competence to achieve teaching target (Thompson et al., 2020). There are direct influences factors to get the target of teaching as well as learning outcomes.

As the Pandemic crossed over the country, online learning has been totally supported by the policy of the government and the educational ministry of the Republic of Indonesia to use in the university (Ali \& Maksum, 2020; Jogezai et al., 2021; Wei et al., 2021). Then, all lecturers in the University of HKBP Nommensen Pematangsiantar were well prepared using the SPADA in learning management system by carrying out socialization, guidance, training and knowledge for lecturers and students of the university. Curriculum, lesson plan, medias as parts of learning management system can be adopted well into SPADA. Online learning management system is effective for learning even though in university level (Adedoyin \& Soykan, 2020; Bahasoan et al., 2020; Febliza \& Okatariani, 2020). Learning activities in online learning management system can improve character of learning experience on campus (Saputro \& Susilowati, 2019). Then, in periods of age, $90 \%$ of the lectures and students use the SPADA were birthed in between 1981-2000 and known as generation Y who were known as the next generation of information and technology development and computer use (Annetta et al., 2013). This generation is also known as the surprising generation in applying technology.

The SPADA succeeds to encounter the various products of online learning technologies such as elearning, Google Classroom, online teaching, WhatsApp and web (Clark \& Mayer, 2016; Singh et al., 2020). The lecturers and students of Nommensen University have used SPADA as the only one media to teach. But, there are several things that need to be considered regarding to the readiness of the students to the total online learning as problem based learning, culture, geographically reason and quality of internet access (Kieschnick, 2020; Savery, 2015). These were the reasons some lecturers taught their classes using Google Classroom and WhatsApp. Also, the major target to achieve the quality of education as it is mentioned in the national education standard. Then, there are scholars and teachers are influenced by the benefits of blended learning (Hrastinski, 2019; Sudiarta \& Sadra, 2016). Research on SPADA has been carried out by several researchers (Jethro et al., 2012; Liza \& Andriyanti, 2020; Maatuk et al., 2021). Each researcher, has a characteristic for the research he did. From several studies. This statement shows that there is a gap regarding the use of SPADA during the Covid-19 period at HKBP Nommensen Pematangsiantar University. With this SPADA application, it is hoped that the English Education Study Program at HKBP Nommensen Pematangsiantar University can apply the same standards to all lecturers who are in charge of course material and can facilitate campus management in controlling, monitoring and evaluating the learning and teaching process, especially during the teaching and 
learning process. covid-19 pandemic this. This research was conducted to apply Social Competence (PASCAL) to increase student learning creativity in the online learning system (SPADA) in the Covid-19 Pandemic Era.

\section{METHOD}

As it is informed above, this research took place during the teaching of the odd semester of 2021 academic year. In the academic year, the lessons served entirely by using SPADA. The students were two groups of students of batch 2020. At the beginning of the research, the lesson was introduced to a group of students by using SPADA and the other group using combination of Google Class room and WhatsApp methods. There were totally 5 groups for Syntactic Structure lessons. Two groups of the students from Syntactic Structure lessons were chosen randomly for the reasons of science and equability. The research design is a quasi-method. The two classes were given pretest and posttest. A class experiment used SPADA and the other class was as controlling class. This research aims to show an investigation of two groups of students of English Syntactic Structure lesson. By purposive sampling technique, the ASCAAL was measured by the result of pre and post-test given to the 45 students and supported by questionnaire. Each group of the English Syntactic Structure consisted of 25 students and 20 students. The group consisted of 25 students was named with experimental class and the other group named with controlling class. One group taught with SPADA and the other group taught with combination teaching media as Google Classroom and WhatsApp. The total number of the students from the two classes is 45 . Then all of the participants of the class followed the data analysis and the lessons according to the research schedules. Technique of data analysis is measured by comparing the results tests of the two classes. The indicators to compare were as: questionnaire, pretest and posttest.

\section{RESULT AND DISCUSSION}

\section{Result}

As the major purpose of this study is to describe the benefits of application social competence as apparatus learning system (ASCAAL) to improve students learning creativity on the in-network learning system (SPADA), the ASCAAL consists of questionnaire, pretest and posttest. The questionnaires were given to students by using Google Form application. By giving questionnaire consisted of indicators as the simplicity, practically, applicability and effectiveness, the aim of receiving data responses to ASCAAL based on their learning activities on SPADA can be proved. Questionnaires were used to measure students' responses to ASCAAL on SPADA. All questionnaires were returned, and 100\% of students indicated that ASCAAL was $100 \%$ simple, practical, applicable and effective. Figure 1 below shows the graph of ASCAAL on SPADA which consists of the simplicity, practically, applicability and effectiveness.

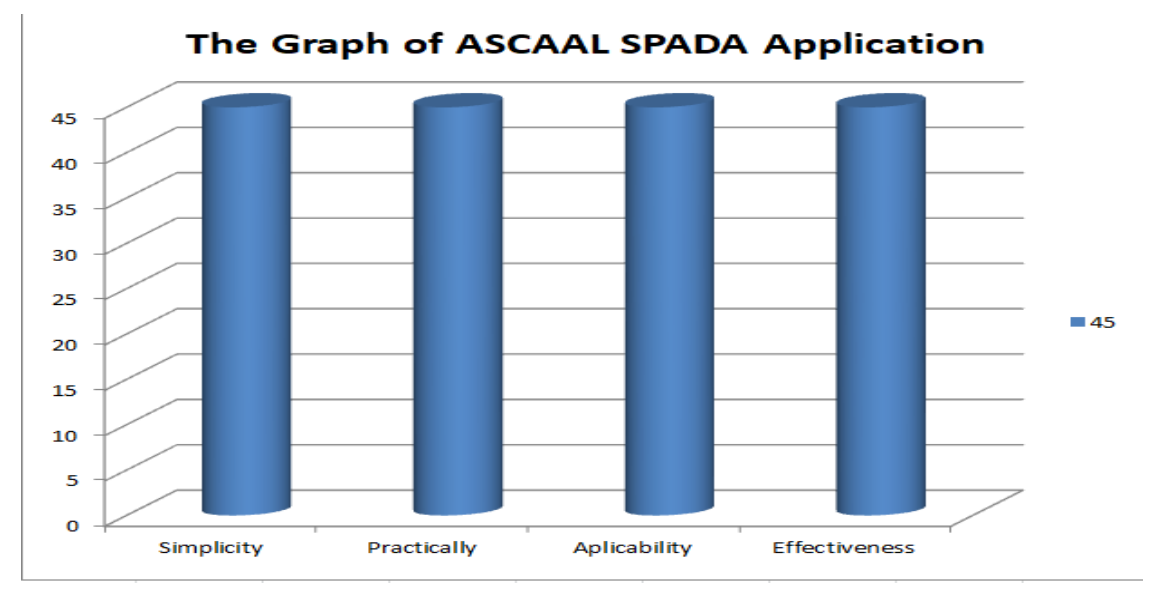

Figure 1. The graph of ASCAAL SPADA application

Based on the data shown in figure 1, there is resume found that the total number of the students was accepted that ASCALL application has simplicity, practically, applicability and effectiveness in their learning activities. The analysis of the ASCAAL works to improve students creativity runs through posttest data and pretest data. Both of the student groups in the controlling class and the experiment class had the same questions for the pretest. The schedule for the pretest was decided at the first day of lessons. The questions were well prepared to measure students understanding about Syntactic Structure. It consisted of 5 questions and served in 
multiple choices form. The questions and the answered were served on SPADA and on the WhatsApp depend on the class. Then based on the schedule posttest, both of the student groups in the controlling class and the experiment class had the same questions for the posttest. The questions were well prepared to measure students understanding about Syntactic Structure. It consisted of 5 questions and served in multiple choices form. The questions and the answered were served on SPADA and on the WhatsApp depend on the class. The total result of the pretest of Group A is still below of the qualified success. The total result of the pretest of group D is still below of the qualified success. Based on the total result of the Post Test of Group A it is found that every student achievement meets the qualified success. Based on the total result of the Post Test of Group D it is found that every student achievement is still below the qualified success. Based on the result of the posttest conducted to the controlling class and the experimental class as it is shown through the tables and the figures, the result shows that student achievement of the experimental class is higher and passed the qualification.

\section{Discussion}

Online learning during this social distancing period must continue to be carried out in order to meet the needs of students (Ferreira et al., 2018; Khalil, 2018; Sajnani \& Mayor, 2020). Several variations of the models and platforms used by lecturers at FKIP University HKBP Nommensen Pematangsiantar are quite good despite the various obstacles that exist. Students as prospective teachers are also required to learn to be technology literate and later be able to develop better online learning (Devi et al., 2020; Ivanov et al., 2019; Sudana et al., 2019). Apart from the influence of social distancing, in this 4.0 industrial revolution era, students should be able to use and develop digital technology in learning (Bui \& Do Van Dung, 2019; Devi et al., 2020; Xu et al., 2018). It is important to develop technology-based learning such as online because it can facilitating better learning and training is gaining momentum around the world, reducing problems associated with traditional learning (AlFraihat et al., 2020; Gavrilenko, 2018; Yusuf \& Widyaningsih, 2020). Online learning should offer students and teachers a common forum to present material and to work together to produce documents. Students process information new knowledge and form new meanings and structures of knowledge (Alias \& Siraj, 2012; Bervell \& Arkorful, 2020; Febliza \& Okatariani, 2020). There is no difference between learning achievement before and after using SPADA because there is only a difference in the way of communication between direct and indirect face-to-face direct. In principle, there is still multi-way communication between lecturers and students (Jamshidi et al., 2020; Prayitno \& Mutianingsih, 2021). This is where the role of lecturers in the online learning process is demanded to be more active and creative in managing learning. Success is influenced by the readiness of lecturers and students. Without reciprocity, of course, it causes obstacles in the implementation of online learning.

\section{CONCLUSION}

ASCAAL as measured by pretest, posttest, and questionnaires has been shown to positively increase students' creativity. ASCAAL also positively supports the learning management system because the flow of teaching communication between teachers and students is effective in e-learning and in the era of information and communication technology that is increasingly developing along a long road to find precedents for teaching media and appropriate teaching methods, virtual classes or online learning proven to be useful for developing social relationships and a sense of community. Then, by using e-learning, teachers and students have easy access and flexibility and help a lot to get learning outcomes and learning satisfaction. Based on the features and menus on SPADA shows a developing learning creativity system that increases student motivation and value.

\section{REFERENCES}

Adedoyin, O. B., \& Soykan, E. (2020). Covid-19 pandemic and online learning: the challenges and opportunities. In Interactive Learning Environments. https://doi.org/10.1080/10494820.2020.1813180.

Al-Fraihat, D., Joy, M., Masa'deh, R., \& Sinclair, J. (2020). Evaluating E-learning systems success: An empirical study. Computers in Human Behavior, 102, 67-86. https://doi.org/10.1016/j.chb.2019.08.004.

Ali, M. K., \& Maksum, H. (2020). Utilization of E-Learning-Based ICT Learning Using the Google Classroom Application During the COVID-19 Pandemic. Journal of Education Research and Evaluation, 4(4), 373. https://doi.org/10.23887/jere.v4i4.29181.

Alias, N., \& Siraj, S. (2012). Effectiveness of Isman Instructional Design Model in Developing Physics Module based on Learning Style and Appropriate Technology. Procedia - Social and Behavioral Sciences, 64. https://doi.org/10.1016/j.sbspro.2012.11.002.

Annetta, L. A., Frazier, W. M., Folta, E., Holmes, S., Lamb, R., \& Cheng, M.-T. (2013). Science teacher efficacy and extrinsic factors toward professional development using video games in a design-based research model: The next generation of STEM learning. Journal of Science Education and Technology, 22(1), 
47-61. https://link.springer.com/article/10.1007/s10956-012-9375-y.

Anuar, S., Nizar, N., \& Ismail, M. A. (2021). The Impact of Using Augmented Reality as Teaching Material on Students' Motivation. Asian Journal of Vocational Education And Humanities, 2(1). https://doi.org/10.53797/ajvah.v2i1.1.2021.

Asrial, Syahrial, Maison, Kurniawan, D. A., \& Piyana, S. O. (2020). Ethnoconstructivism E-Module to Improve Perception, Interest, and Motivation of Students in Class V Elementary School. JPI (Jurnal Pendidikan Indonesia), 9(1), 30-41. https://doi.org/10.23887/jpi-undiksha.v9i1.19222.

Atabekova, A., Lutskovskaia, L., \& Gorbatenko, R. (2021). Developing multiliteracy skills and pragmatic communication awareness of university students learning a foreign language (English) for specific purposes. Thinking Skills and Creativity, 29. https://doi.org/10.1016/j.tsc.2021.100956.

Bahasoan, A., Ayuandiani, W., Mukhram, M., \& Rahmat, A. (2020). Effectiveness of Online Learning In Pandemic Covid-19. Jurnal Kajian Pendidikan Dan Hasil Penelitian, 6(3), 100-106. https://doi.org/10.46729/ijstm.v1i2.30.

Bervell, B., \& Arkorful, V. (2020). LMS-enabled blended learning utilization in distance tertiary education: establishing the relationships among facilitating conditions, voluntariness of use and use behaviour. International Journal of Educational Technology in Higher Education, 17(1), 6. https://doi.org/10.1186/s41239-020-0183-9.

Bettencourt, C., Velho, J. L., \& Almeida, P. A. (2011). Biology teachers' perceptions about ScienceTechnology-Society (STS) education. Procedia - Social and Behavioral Sciences, 15. https://doi.org/10.1016/j.sbspro.2011.04.262.

Bui, V. H., \& Do Van Dung. (2019). Development of Vietnamese Vocational Education Teachers to adapt the Industrial Revolution 4.0. Asian Journal of Interdisciplinary Research, 2(4), 1-7. https://doi.org/10.34256/ajir1941.

Chan, C. S. C. (2021). Helping university students discover their workplace communication needs: An eclectic and interdisciplinary approach to facilitating on-the-job learning of workplace communication. English for Specific Purposes, 64. https://doi.org/10.1016/j.esp.2021.07.002.

Chasanah, C. (2020). The Effectiveness of Learning Models on Written Mathematical Communication Skills Viewed from Students' Cognitive Styles. European Journal of Educational Research, 9(3), 979-994. https://doi.org/10.12973/eu-jer.9.3.979.

Clark, R. C., \& Mayer, R. E. (2016). E-learning and the science of instruction: Proven guidelines for consumers and designers of multimedia learning. john Wiley \& sons.

Coffelt, T. A., Grauman, D., \& Smith, F. L. M. (2019). Employers' Perspectives on Workplace Communication Skills: The Meaning of Communication Skills. Business and Professional Communication Quarterly, 82(4), 418-439. https://doi.org/10.1177/2329490619851119.

Dado, M., \& Bodemer, D. (2017). A review of methodological applications of social network analysis in computer-supported collaborative learning. Educational Research Review, 22, 159-180. https://doi.org/10.1016/j.edurev.2017.08.005.

Devi, M., Annamalai, M. A. R., \& Veeramuthu, S. P. (2020). Literature education and industrial revolution 4.0. Universal Journal of Educational Research, 8(3), 1027-1036. https://doi.org/10.13189/ujer.2020.080337.

Dhiu, K. D. (2017). Learning Motivation And Perception Of The Teachers' Pedagogic Competence And Learning Achievement In Social Science Of Junior High School Students. Journal of Education Technology, 1(1), 6-12. https://doi.org/10.23887/jet.v1i1.10078.

Febliza, A., \& Okatariani, O. (2020). The Development of Online Learning Media by Using Moodle for General Chemistry Subject. Journal of Educational Science and Technology (EST), 6(1), 40. https://doi.org/10.26858/est.v6i1.12339.

Ferreira, J., Behrens, M., Torres, P., \& Marriott, R. (2018). The necessary knowledge for online education: Teaching and learning to produce knowledge. Eurasia Journal of Mathematics, Science and Technology Education, 14(6). https://doi.org/10.29333/ejmste/86463.

Gavrilenko, N. (2018). Online model for teaching and learning the specialized translation. Eurasia Journal of Mathematics, Science and Technology Education, 14(6), 2711-2717. https://doi.org/10.29333/ejmste/85421.

Gishti, E. (Shehi). (2018). Social Partnership in Vocational Education and Training in Albania. European Journal of Education, 1(3), 163-169. https://doi.org/10.26417/ejed.v1i3.p163-169.

Hrastinski, S. (2019). What Do We Mean by Blended Learning? TechTrends. https://doi.org/10.1007/s11528019-00375-5.

Ivanov, D., Dolgui, A., \& Sokolov, B. (2019). The impact of digital technology and Industry 4.0 on the ripple effect and supply chain risk analytics. International Journal of Production Research, 57(3), 829-846. 
https://doi.org/10.1080/00207543.2018.1488086.

Jamshidi, M., Lalbakhsh, A., Talla, J., Peroutka, Z., Hadjilooei, F., Lalbakhsh, P., Jamshidi, M., La Spada, L., Mirmozafari, M., \& Dehghani, M. (2020). Artificial intelligence and COVID-19: deep learning approaches for diagnosis and treatment. Ieee Access, 8, 109581-109595. https://www.ncbi.nlm.nih.gov/pmc/articles/PMC8043506/.

Jayadiputra, E., \& Karim, A. A. (2020). 21st Century Competences in Civic Education Curriculum of Indonesia. 2nd Annual Civic Education Conference (ACEC 2019), 99-102. https://doi.org/10.2991/assehr.k.200320.019.

Jethro, O. O., Grace, A. M., \& Thomas, A. K. (2012). E-learning and its effects on teaching and learning in a global age. International Journal of Academic Research in Business and Social Sciences, 2(1), 203. http://ijeim.iseeadyar.org/articles/e-learning-and-its-effects-on-teaching-and-learning-in-a-global-age.

Jogezai, N. A., Baloch, F. A., Jaffar, M., Shah, T., Khilji, G. K., \& Bashir, S. (2021). Teachers' attitudes towards social media (SM) use in online learning amid the COVID-19 pandemic: the effects of SM use by teachers and religious scholars during physical distancing. Heliyon, 7(4). https://doi.org/10.1016/j.heliyon.2021.e06781.

Khalil, Z. M. (2018). EFL Students' Perceptions towards Using Google Docs and Google Classroom as Online Collaborative Tools in Learning Grammar. Applied Linguistics Research Journal, 2(2), 33-48. https://doi.org/10.14744/alrj.2018.47955.

Khan, M. A., Vivek, Nabi, M. K., Khojah, M., \& Tahir, M. (2021). Students' Perception towards E-Learning During Covid-19 Pandemic In India: An Empirical Study. Sustainability, 13(1). https://doi.org/10.3390/su13010057.

Kieschnick, J. (2020). The impact of Buddhism on Chinese material culture. Princeton University Press.

Liu, I.-F. (2020). The impact of extrinsic motivation, intrinsic motivation, and social self-efficacy on English competition participation intentions of pre-college learners: Differences between high school and

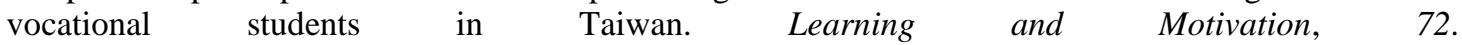
https://doi.org/10.1016/j.lmot.2020.101675.

Liza, K., \& Andriyanti, E. (2020). Digital Literacy Scale of English Pre-Service Teachers and Their Perceived Readiness toward the Application of Digital Technologies. Journal of Education and Learning (EduLearn), 14(1), 74-79. https://doi.org/10.11591/edulearn.v14i1.13925.

Maatuk, A. M., Elberkawi, E. K., Aljawarneh, S., Rashaideh, H., \& Alharbi, H. (2021). The COVID-19 Pandemic and E-learning: Challenges and Opportunities from the Perspective of Students and Instructors. Journal of Computing in Higher Education, 1-18. https://doi.org/https://link.springer.com/article/10.1007/s12528-021-09274-2.

Maulida, I., Dibia, I. K., \& Astawan, I. G. (2020). The Development of Social Attitude Assessment Instrument and Social Studies Learning Outcomes Grade IV on Theme of Indahnya Keragaman di Negeriku. Indonesian Journal Of Educational Research and Review, 3(1), 12. https://doi.org/10.23887/ijerr.v3i2.25823.

Mufit, F., Asrizal, Hanum, S. ., \& Fadhilah, A. (2020). Preliminary research in the development of physics teaching materials that integrate new literacy and disaster literacy Preliminary research in the development of physics teaching materials that integrate new literacy and disaster literacy. The 2nd International Conference on Research and Learning of Physics, 0-12. https://doi.org/10.1088/17426596/1481/1/012041.

Nácher, M. J., Badenes-Ribera, L., Torrijos, C., \& Ballesteros, M. A. (2021). The effectiveness of the GoKoan elearning platform in improving university students' academic performance. Studies in Educational Evaluation, 70. https://doi.org/10.1016/j.stueduc.2021.101026.

Nácher, M. J., Badenes-Ribera, L., Torrijos, C., Ballesteros, M. A., \& Cebadera, E. (2021). The effectiveness of the GoKoan e-learning platform in improving university students' academic performance. Studies in Educational Evaluation, 70. https://doi.org/10.1016/j.stueduc.2021.101026.

Ogbonna, C. G., Ibezim, N. E., \& Obi, C. A. (2019). Synchronous versus asynchronous e-learning in teaching word processing: An experimental approach. South African Journal of Education, 39(2), 1-15. https://doi.org/10.15700/saje.v39n2a1383.

Prayitno, L. L., \& Mutianingsih, N. (2021). Penggunaan SPADA Selama Masa Covid-19. Wahana: Tridarma Perguruan Tinggi, 73(1), 19-29. https://doi.org/10.36456/wahana.v73i1.3876.

Retnawati, H., Hadi, S., \& Nugraha, A. C. (2016). Vocational High School Teachers' Difficulties in Implementing the Assessment in Curriculum 2013 in Yogyakarta Province of Indonesia. International Journal of Instruction, 9(1), 33-48. https://doi.org/10.12973/iji.2016.914a.

Sajnani, N., \& Mayor, C. et al. (2020). Aesthetic presence: The role of the arts in the education of creative arts therapists in the classroom and online. Arts in Psychotherapy, 69(February), 101668. https://doi.org/10.1016/j.aip.2020.101668. 
Saputro, B., \& Susilowati, A. T. (2019). Effectiveness of learning management system (LMS) on in-network learning system (Spada) based on scientific. Journal for the Education of Gifted Young Scientists, 7(3), 481-498. https://doi.org/10.17478/jegys.606029.

Savery, J. R. (2015). Overview of problem-based learning: Definitions and distinctions. Essential Readings in Problem-Based Learning: Exploring and Extending the Legacy of Howard S. Barrows, 9, 5-15. https://doi.org/10.7771/1541-5015.1002.

Singh, C. K. S., Singh, T. S. M., Abdullah, N. Y., Moneyam, S., Ismail, M. R., Tek, E., Karupayah, T., Chenderan, K., Singh, M. K. R., \& Singh, J. K. S. (2020). Rethinking English language teaching through Telegram, Whatsapp, Google classroom and Zoom. Systematic Reviews in Pharmacy, 11(11), 45-54. https://doi.org/10.31838/srp.2020.11.9.

Siripongdee, K., Pimdee, P., \& Tuntiwongwanich, S. (2020). A blended learning model with IoT-based technology: effectively used when the COVID-19 pandemic? Journal for the Education of Gifted Young Scientists, 8(2), 905-917. https://doi.org/10.17478/jegys.698869.

Sudana, I., Apriyani, D., \& Nurmasitah, S. (2019). Revitalization of vocational high school roadmap to encounter the 4.0 industrial revolution. Journal of Social Sciences Research, 5(2), 338-342. https://doi.org/10.32861/jssr.52.338.342.

Sudiarta, \& Sadra. (2016). Pengaruh model blended learning berbantuan video animasi terhadap kemampuan pemecahan masalah dan pemahaman konsep siswa. Jurnal Pendidikan Dan Pengajaran, 49(2), 48-58. https://doi.org/10.23887/jppundiksha.v49i2.9009.

Sundayana, W. (2015). Readiness and competence of senior high school English teachers to implement Curriculum 2013. Indonesian Journal of Applied Linguistics, 5(1), $29-36$. https://doi.org/10.17509/ijal.v5i1.828.

Suryandari, K. C. (2020). Spada-Based Learning in The Covid-19 Priode Primary Teacher Traning Education Faculty of Teacher Training and Education Sebelas Maret University. Proceedings of the 4th International Conference on Learning Innovation and Quality Education, 1-6. https://doi.org/10.1145/3452144.3453781.

Tentama, F., \& Riskiyana, E. R. (2020). The role of social support and self-regulation on work readiness among students in vocational high school. International Journal of Evaluation and Research in Education, 9(4), 826-832. https://doi.org/10.11591/ijere.v9i4.20578.

Thompson, A. M., Stinson, A. E., Sinclair, J., Stormont, M., Prewitt, S., \& Hammons, J. (2020). Changes in Disruptive Behavior Mediated by Social Competency: Testing the STARS Theory of Change in a Randomized Sample of Elementary Students. Journal of the Society for Social Work and Research, 11(4), 591-614. https://www.journals.uchicago.edu/doi/abs/10.1086/712494.

Tsai, H. C., Jou, M., Wang, J. Y., \& Huang, C. C. (2017). An empirical study on the incorporation of APP and progressive reasoning teaching materials for improving technical creativity amongst students in the subject of automatic control. Computers in Human Behavior, 75, 997-1007. https://doi.org/10.1016/j.chb.2016.10.031.

Tyas, M. A., Nurkamto, J., Marmanto, S., \& Laksani, H. (2019). Developing higher order thinking skills (HOTS)-Based questions: Indonesian EFL teachers' challenges. Proceeding of the 2nd International Conference on Future of Education, 2(1), 52-63. https://doi.org/10.17501/26307413.2019.2106.

Uygarer, R., \& Uzunboylu, H. (2017). An investigation of the digital teaching book compared to traditional books in distance education of teacher education programs. Eurasia Journal of Mathematics, Science and Technology Education, 13(8), 5365-5377. https://doi.org/10.12973/eurasia.2017.00830a.

Vrieling, E. M., Bastiaens, T. J., \& Stijnen, S. (2012). Effects of increased self-regulated learning opportunities on student teachers' metacognitive and motivational development. International Journal of Educational Research, 53. https://doi.org/10.1016/j.ijer.2012.03.014

Wei, X., Saab, N., \& Admiraal, W. (2021). Assessment of cognitive, behavioral, and affective learning outcomes in massive open online courses: A systematic literature review. Computers \& Education, 163. https://doi.org/10.1016/j.compedu.2020.104097.

Xu, M., David, J. M., \& Kim, S. H. (2018). The fourth industrial revolution: Opportunities and challenges. International Journal of Financial Research, 9(2), 90-95. https://doi.org/10.5430/ijfr.v9n2p90.

Yilmaz, E., \& Korur, F. (2021). The Effects of an Online Teaching Material Integrated Methods on Students' Science Achievement, Attitude and Retention. International Journal of Technology in Education, 4(1). https://doi.org/10.46328/ijte.79.

Yusuf, I., \& Widyaningsih, S. W. (2020). Implementing e-learning-based virtual laboratory media to students' metacognitive skills. International Journal of Emerging Technologies in Learning, 15(5), 63-74. https://doi.org/10.3991/ijet.v15i05.12029.

Zendler, A., \& Greiner, H. (2020). The effect of two instructional methods on learning outcome in chemistry 
education: The experiment method and computer simulation. Education for Chemical Engineers. https://doi.org/10.1016/j.ece.2019.09.001.

Zhang, Y., Ghandour, A., \& Shestak, V. (2020). Using Learning Analytics to Predict Students Performance in Moodle LMS. International Journal of Emerging Technologies in Learning. https://doi.org/10.3991/ijet.v15i20.15915. 